\section{Caneburning Effects on Weeds, Primocane Growth, and Fruit Yield in Pacific Northwest Red Raspberry}

\author{
Yushan Duan \\ Northwestern Washington Research and Extension Center, Washington State \\ University, 16650 State Route 536, Mount Vernon, WA 98273
}

Thomas W. Walters
Walters Ag Research, 2117 Meadows Lane, Anacortes, WA 98221

Timothy W. Miller ${ }^{1}$

Northwestern Washington Research and Extension Center, Washington State University, 16650 State Route 536, Mount Vernon, WA 98273

Additional index words. Rubus idaeus, carfentrazone, oxyfluorfen, terbacil, 'Meeker', 'Cascade Bounty', 'Coho', floricane

\begin{abstract}
A large percentage of North American processing red raspberry (Rubus idaeus L.) is produced in maritime areas of western regions in Washington, British Columbia, and Oregon. Most of these raspberry plantings are caneburned; they are treated with herbicides in early spring to remove the first-emerging primocanes in an attempt to reduce their competition with floricanes during flowering and fruiting and thereby increase fruit yield. Trials were conducted in northwestern Washington to determine the effect of carfentrazone and oxyfluorfen applied for primocane management in three currently grown raspberry cultivars. Although caneburning did provide early season weed control in treated plots, weed control fell below $70 \%$ in the commercial 'Meeker' field more quickly each year: at 138 days after treatment (DAT) in 2010, 71 DAT in 2011, and 47 DAT in 2012, compared with greater than $80 \%$ control at the end of each season when the soil residual herbicide terbacil was applied. Oxyfluorfen provided longer suppression of primocane growth than did carfentrazone, particularly in 'Cascade Bounty' but also to a lesser extent in 'Meeker'. Caneburning did not improve raspberry yield in five of the six tested years for 'Meeker', or in any of the five tested years for 'Cascade Bounty' or the single year for 'Coho', although the trend was for greater yield with caneburning across all cultivars. Oxyfluorfen improved 3-year 'Meeker' average yield $43 \%$ from nontreated raspberry in the commercial field trial, compared with a $29 \%$ increase with carfentrazone.
\end{abstract}

The Pacific Northwest (PNW) region produces most of the North American crop of processed red raspberry (Rubus idaeus L.) annually, with Washington accounting for $58 \%$ of the region's $45,000 \mathrm{t}$ of fruit produced in 2015 (Raspberry Industry Development Council, 2016; USDA-NASS, 2016). Red raspberry has perennial roots and biennial aboveground shoots. It produces primocanes in the first year, which overwinter and became floricanes in the second year (Crandall, 1995). Although both primocanes and floricanes are capable of producing berries in primocane-fruiting raspberry, floricanefruiting raspberry, which produces berries only from floricanes, is predominantly grown in the PNW where the climate is relatively cool and mild (Pritts, 2008). In floricanefruiting raspberry, photosynthates produced by primocane leaves contribute more to root growth than to floral development (Fernandez

Received for publication 19 Dec. 2016. Accepted for publication 21 Mar. 2017.

${ }^{1}$ Corresponding author. E-mail: twmiller@wsu. edu. 1983; Norton, 1980). Caneburning also aids early season weed control in crop rows
(Miller et al., 2008). When first developed in the 1970s, up to three applications of dinoseb were applied per season to the most popular red raspberry 'Willamette', increasing berry yield by an average of $52 \%$ (Norton, 1973, 1980; Sheets, 1973). Since that time, the herbicides carfentrazone and oxyfluorfen have replaced dinoseb for this use in the PNW, 'Meeker' has replaced 'Willamette' as the most widely grown raspberry cultivar in the PNW, and more efficient berry harvesters have been developed (Howard and Cameron, 1990; Howard et al., 1989). However, growers believe that the conditions and outcomes described in these older reports are still applicable to current PNW raspberry production practices and cultivars. Yet, even in initial trials cited above, caneburning was not universally effective at increasing berry yield. Of seven PNW raspberry cultivars tested since the late 1970s, caneburning consistently increased berry yield of only four: 'Willamette', 'Chilcotin', 'Nootka', and 'Skeena' (Freeman and Daubeny, 1986; Howard and Cameron, 1990; Lawson, 1980; Miller et al., 2008; Norton, 1980, 1981). The objectives of this study were, therefore, to assess and compare 1) the effect of caneburning herbicide application for weed control, 2) the reproductive response of three current red raspberry cultivars to caneburning, and 3) to determine whether caneburning is still a beneficial practice for PNW red raspberry production.

\section{Materials and Methods}

Commercial field trial. Whole-row trials were conducted in three fields of three wellestablished red raspberry cultivars. Separate fields of 'Coho' and 'Meeker' raspberry were located near Allen, WA $\left(48^{\circ} 50^{\prime} \mathrm{N}\right.$, $\left.122^{\circ} 38^{\prime} \mathrm{W}^{\prime \prime}\right)$, and the 'Cascade Bounty' field was near Lynden, WA $\left(48^{\circ} 91^{\prime} \mathrm{N}\right.$, $122^{\circ} 42^{\prime} \mathrm{W}^{\prime \prime}$ ). 'Coho' plots were $\approx 137 \mathrm{~m}$ long by $3 \mathrm{~m}$ wide, 'Meeker' plots were $169 \mathrm{~m}$ long by $3 \mathrm{~m}$ wide, and 'Cascade Bounty' plots were $114 \mathrm{~m}$ long by $3 \mathrm{~m}$ wide. Each plot contained a single row of raspberry canes. Herbicide treatments were applied once per year from late March to early April as directed sprays to 10 to $15 \mathrm{~cm}$, firstemerged primocanes using a tractor-mounted sprayer delivering a volume of $278 \mathrm{~L} \cdot \mathrm{ha}^{-1}$. Carfentrazone $\left(0.02 \mathrm{~kg} \cdot \mathrm{ha}^{-1}\right)$ or oxyfluorfen $\left(0.11 \mathrm{~kg} \cdot \mathrm{ha}^{-1}\right)$ was the caneburning herbicide, and terbacil $\left(1.34 \mathrm{~kg} \cdot \mathrm{ha}^{-1}\right)$ was applied for residual weed control. Treatments at all locations were carfentrazone, oxyfluorfen, and terbacil applied alone, whereas 'Meeker' and 'Coho' fields also received mixtures of terbacil and carfentrazone or oxyfluorfen. Nontreated control plots were included at all sites. Herbicides were applied to the same plots of 'Meeker' in 2010, 2011, and 2012, to 'Coho' in 2010, and to 'Cascade Bounty' in 2011 and 2012. The 'Coho' trial was ended in 2011 because of the inadvertent application of carfentrazone to all plots by the grower and subsequent destruction of all raspberry plants in the field after the 2011 harvest. 
Weed control percentage was visually estimated within each treated plot $(0 \%$ control $=$ no weed injury from the herbicide treatment and $100 \%=$ no weeds present) as compared with nontreated plots (by definition $0 \%$ control) at about 2-week intervals during the raspberry growing season (May through September) for 3 years. In each plot, 10-15 primocanes were selected 1 month after caneburning and were marked with colored tapes. Length (centimeters) and diameter (millimeters) of these primocanes were collected from all trials at about 2-week intervals during the raspberry growing season. Primocane length was measured from the soil surface to the tip of the most recently emerged leaf, whereas diameter of the basal part of the cane at about $10 \mathrm{~cm}$ above the soil surface was measured using a caliper. Primocane growth rate $\left(\mathrm{cm} \cdot \mathrm{d}^{-1}\right)$ was calculated by dividing the length difference between two consecutive measurements by the time interval:
Primocane Growth Rate

$$
\begin{aligned}
= & \left(\text { Primocane Length }_{(x+1)}\right. \\
& \left.- \text { Primocane Length }_{x}\right) /\left(d_{(x+1)}-d_{x}\right) ;
\end{aligned}
$$

where $(x+1)$ represents the event of measurement and $x$ represents the previous event of measurement ( $x$ begins at 0 ).

The 2010 raspberry harvests occurred from early June to mid-August, whereas the 2011 and 2012 harvests occurred from midJuly to mid-August. Berries were harvested using grower-owned equipment: a Side-Row Harvester (Littau Harvester, Stayton, OR) for 'Meeker' and 'Coho' and an Oxbo 900 Raspberry Harvester (Oxbo Intl. Corp., Labelle, FL) for 'Cascade Bounty'. Berries were machine-picked several times each week in all trials, and fruit weights were combined to determine total yield for each treatment and cultivar in each trial every year.
Research field trial. This small-plot trial was conducted in well-established 'Meeker' and 'Cascade Bounty' at the Washington State University Northwestern Washington Research and Extension Center $\left(48^{\circ} 44^{\prime} \mathrm{N}\right.$, $122^{\circ} 39^{\prime} \mathrm{W}^{\prime \prime}$ ) located near Mount Vernon, WA. Plots measured $9.1 \mathrm{~m}$ long by $3 \mathrm{~m}$ wide. Carfentrazone and oxyfluorfen were applied to newly emerged primocanes measuring 10 to $15 \mathrm{~cm}$ tall using a $\mathrm{CO}_{2}$-pressurized backpack sprayer delivering $327 \mathrm{~L} \cdot \mathrm{ha}^{-1}$ from late March to early April in 2010-12. Each plot received the same herbicide treatment every spring. Products were applied at the same rate and manner as in the commercial field trials, and nontreated control plots were included.

Because few weeds were present, weed control was not estimated in the research field trial. Seven primocanes were selected and marked for growth measurements as described in the commercial field trials. Raspberry harvests also occurred at a similar

\begin{tabular}{|c|c|c|c|c|c|c|c|c|}
\hline \multirow[b]{3}{*}{ Cultivar } & \multirow[b]{3}{*}{ Treatment $^{\mathrm{z}}$} & \multicolumn{7}{|c|}{ Days after treatment } \\
\hline & & 43 & 63 & 80 & 92 & 105 & 121 & 138 \\
\hline & & \multicolumn{7}{|c|}{ Weed control (\%) } \\
\hline \multirow[t]{5}{*}{ Meeker } & Carfentrazone & $87 b^{y}$ & $82 \mathrm{~b}$ & $71 \mathrm{~d}$ & $69 \mathrm{c}$ & $62 \mathrm{c}$ & $74 \mathrm{c}$ & $\overline{60 \mathrm{c}}$ \\
\hline & Oxyfluorfen & $86 \mathrm{~b}$ & $88 \mathrm{~b}$ & $85 \mathrm{c}$ & $81 \mathrm{~b}$ & $78 \mathrm{~b}$ & $73 \mathrm{c}$ & $70 \mathrm{~b}$ \\
\hline & Terbacil & $88 \mathrm{~b}$ & $94 \mathrm{a}$ & $91 \mathrm{~b}$ & $92 \mathrm{a}$ & $92 \mathrm{a}$ & $92 \mathrm{a}$ & $92 \mathrm{a}$ \\
\hline & Carfentrazone + terbacil & $93 \mathrm{a}$ & $95 \mathrm{a}$ & $94 \mathrm{ab}$ & $93 \mathrm{a}$ & $92 \mathrm{a}$ & $92 \mathrm{a}$ & $89 a$ \\
\hline & Oxyfluorfen + terbacil & $96 \mathrm{a}$ & $97 \mathrm{a}$ & $97 \mathrm{a}$ & $97 \mathrm{a}$ & $97 \mathrm{a}$ & $83 \mathrm{a}$ & $95 \mathrm{a}$ \\
\hline \multirow[t]{5}{*}{ Coho } & Carfentrazone & $89 \mathrm{c}$ & $73 \mathrm{~b}$ & $69 \mathrm{~b}$ & $62 \mathrm{~b}$ & $61 \mathrm{~b}$ & $48 \mathrm{~b}$ & $51 \mathrm{~b}$ \\
\hline & Oxyfluorfen & $74 \mathrm{~d}$ & $76 \mathrm{~b}$ & $55 \mathrm{c}$ & $58 \mathrm{~b}$ & $54 \mathrm{c}$ & $48 \mathrm{~b}$ & $52 \mathrm{~b}$ \\
\hline & Terbacil & $93 \mathrm{~b}$ & $98 \mathrm{a}$ & $97 \mathrm{a}$ & $94 \mathrm{a}$ & $95 \mathrm{a}$ & $95 \mathrm{a}$ & $95 \mathrm{a}$ \\
\hline & Carfentrazone + terbacil & $97 \mathrm{a}$ & $99 \mathrm{a}$ & $98 \mathrm{a}$ & $97 \mathrm{a}$ & $94 \mathrm{a}$ & $95 \mathrm{a}$ & $95 \mathrm{a}$ \\
\hline & Oxyfluorfen + terbacil & $96 \mathrm{ab}$ & $100 \mathrm{a}$ & $99 \mathrm{a}$ & $99 \mathrm{a}$ & $99 \mathrm{a}$ & $98 \mathrm{a}$ & $97 \mathrm{a}$ \\
\hline
\end{tabular}

Table 1. Percent weed control of 'Meeker' and 'Coho' red raspberry throughout the growing season in the commercial field trials in 2010.

${ }^{\mathrm{z}}$ Carfentrazone, oxyfluorfen, and terbacil were direct-applied at $0.02,0.11$, and $1.34 \mathrm{~kg} \cdot \mathrm{ha}^{-1}$, respectively, in early spring when first-emerging primocanes were 10 to $15 \mathrm{~cm}$ tall. ${ }^{\mathrm{y}}$ Cultivar means in each measurement date followed by the same letter are not significantly different based on Tukey's honestly significant difference method $(P \leq 0.05)$.

\begin{tabular}{|c|c|c|c|c|c|c|c|c|c|}
\hline \multirow[b]{3}{*}{ Cultivar } & \multirow[b]{3}{*}{ Treatment $^{\mathrm{z}}$} & \multicolumn{8}{|c|}{ Days after treatment } \\
\hline & & 33 & 57 & 71 & 88 & 90 & 113 & 127 & 142 \\
\hline & & \multicolumn{8}{|c|}{ Weed control $(\%)$} \\
\hline \multirow[t]{5}{*}{ Meeker } & Carfentrazone & $87 b^{y}$ & $81 \mathrm{~b}$ & $69 \mathrm{~b}$ & $69 \mathrm{~b}$ & $63 \mathrm{~b}$ & $66 \mathrm{~b}$ & $60 \mathrm{~b}$ & $55 \mathrm{~b}$ \\
\hline & Oxyfluorfen & $86 \mathrm{~b}$ & $75 \mathrm{~b}$ & $68 \mathrm{~b}$ & $60 \mathrm{~b}$ & $56 \mathrm{~b}$ & $51 \mathrm{~b}$ & $55 \mathrm{~b}$ & $47 \mathrm{~b}$ \\
\hline & Terbacil & $96 \mathrm{ab}$ & $97 \mathrm{a}$ & $95 \mathrm{a}$ & $95 \mathrm{a}$ & $96 \mathrm{a}$ & $95 \mathrm{a}$ & $92 \mathrm{a}$ & $91 \mathrm{a}$ \\
\hline & Carfentrazone + terbacil & $98 \mathrm{a}$ & $98 \mathrm{a}$ & $97 \mathrm{a}$ & $97 \mathrm{a}$ & $97 \mathrm{a}$ & $97 \mathrm{a}$ & $97 \mathrm{a}$ & $96 \mathrm{a}$ \\
\hline & Oxyfluorfen + terbacil & $98 \mathrm{a}$ & $98 \mathrm{a}$ & $96 \mathrm{a}$ & $97 \mathrm{a}$ & $96 \mathrm{a}$ & $97 \mathrm{a}$ & $96 \mathrm{a}$ & $96 \mathrm{a}$ \\
\hline \multirow[t]{3}{*}{ Cascade Bounty } & Carfentrazone & $96 \mathrm{~b}$ & $95 \mathrm{~b}$ & $97 \mathrm{a}$ & $95 \mathrm{~b}$ & $92 \mathrm{~b}$ & $95 \mathrm{~b}$ & $97 \mathrm{a}$ & $96 \mathrm{~b}$ \\
\hline & Oxyfluorfen & $98 \mathrm{ab}$ & $97 \mathrm{ab}$ & $99 \mathrm{a}$ & $97 \mathrm{ab}$ & $98 \mathrm{ab}$ & $97 \mathrm{ab}$ & $98 \mathrm{a}$ & $98 \mathrm{ab}$ \\
\hline & Terbacil & $99 \mathrm{a}$ & $99 \mathrm{a}$ & $99 \mathrm{a}$ & $100 \mathrm{a}$ & $99 \mathrm{a}$ & $99 \mathrm{a}$ & $100 \mathrm{a}$ & $100 \mathrm{a}$ \\
\hline
\end{tabular}

Table 2. Percent weed control of 'Meeker' and 'Cascade Bounty' red raspberry throughout the growing season in the commercial field trial in 2011.

${ }^{\mathrm{z}}$ Carfentrazone, oxyfluorfen, and terbacil were direct-applied at $0.02,0.11$, and $1.34 \mathrm{~kg} \cdot \mathrm{ha}^{-1}$, respectively, in early spring when first-emerging primocanes were 10 to $15 \mathrm{~cm}$ tall

${ }^{\mathrm{y}}$ Cultivar means in each measurement date followed by the same letter are not significantly different based on Tukey's honestly significant difference method $(P \leq 0.05)$.

\begin{tabular}{|c|c|c|c|c|c|c|}
\hline \multirow[b]{3}{*}{ Cultivar } & \multirow[b]{3}{*}{ Treatment $^{z}$} & \multicolumn{5}{|c|}{ Days after treatment } \\
\hline & & 33 & 47 & 68 & 87 & 102 \\
\hline & & \multicolumn{5}{|c|}{ Weed control (\%) } \\
\hline \multirow[t]{5}{*}{ Meeker } & Carfentrazone & $79 c^{y}$ & $69 \mathrm{~b}$ & $48 \mathrm{c}$ & $39 \mathrm{c}$ & $46 \mathrm{c}$ \\
\hline & Oxyfluorfen & $46 \mathrm{~d}$ & $39 \mathrm{c}$ & $11 \mathrm{~d}$ & $22 \mathrm{~d}$ & $16 \mathrm{~d}$ \\
\hline & Terbacil & $88 \mathrm{~b}$ & $84 \mathrm{a}$ & $79 \mathrm{~b}$ & $77 \mathrm{~b}$ & $82 \mathrm{~b}$ \\
\hline & Carfentrazone + terbacil & 99 a & $94 \mathrm{a}$ & $97 \mathrm{a}$ & $98 \mathrm{a}$ & $96 \mathrm{a}$ \\
\hline & Oxyfluorfen + terbacil & $97 \mathrm{a}$ & $92 \mathrm{a}$ & $91 \mathrm{a}$ & $88 \mathrm{ab}$ & $84 \mathrm{~b}$ \\
\hline \multirow[t]{3}{*}{ Cascade Bounty } & Carfentrazone & $96 \mathrm{~b}$ & $98 \mathrm{~b}$ & $96 \mathrm{~b}$ & $95.4 \mathrm{~b}$ & $93 \mathrm{a}$ \\
\hline & Oxyfluorfen & $98 \mathrm{ab}$ & $99 \mathrm{ab}$ & $99 \mathrm{a}$ & $93.1 \mathrm{~b}$ & $85 \mathrm{a}$ \\
\hline & Terbacil & $100 \mathrm{a}$ & $100 \mathrm{a}$ & $100 \mathrm{a}$ & $100 \mathrm{a}$ & $91 \mathrm{a}$ \\
\hline
\end{tabular}

Table 3. Percent weed control of 'Meeker' and 'Cascade Bounty' red raspberry throughout the growing season in the commercial field trial in 2012.

${ }^{\mathrm{z}}$ Carfentrazone, oxyfluorfen, and terbacil were direct-applied at $0.02,0.11$, and $1.34 \mathrm{~kg} \cdot \mathrm{ha}^{-1}$, respectively, in early spring when first-emerging primocanes were 10 to $15 \mathrm{~cm}$ tall

${ }^{\mathrm{y}}$ Cultivar means in each measurement date followed by the same letter are not significantly different based on Tukey's honestly significant difference method $(P \leq 0.05)$. 
timing and manner as in the commercial field trials, although an Over-The-Row Harvester (Littau Harvester) was used for fruit harvest.

Statistical analysis. The experimental design for all trials was a randomized complete block. Each site in the commercial field trial contained three replicates, and the research field trial contained five replicates. Because each of the three fields in the commercial field trial was planted to a single cultivar, they were analyzed separately for response to caneburning treatments, whereas the two cultivars in the research field trial were planted in a random assignment to separate plots and thus cultivar could be included in those analyses. Total berry yield and primocane growth rate were analyzed using a generalized linear model procedure.
Primocane growth and weed control were analyzed using a mixed-effect model for repeated experiment procedure. An AR(1) covariance structure was used as the optimum for repeated measures as based on the minimum AICc value criteria. SAS 9.2 software (SAS Institute, Inc., Cary, NC) was used for all analyses. Means were separated using Tukey's honestly significant difference method $(P \leq 0.05)$.

\section{Results}

Commercial field trials. Weed control percentage was only visually estimated in the commercial field trial. Panicle willowweed (Epilobium brachycarpum C. Presl.) was the dominant weed species in 'Meeker' and 'Coho' raspberry plots, whereas Canada thistle (Cirsium arvense L. Scop.) and broadleaf dock (Rumex obtusifolius L.) were also found to a lesser extent. A sparse population of common mallow (Malva neglecta Wallr.) and creeping bentgrass (Agrostis stolonifera L.) was present in 'Cascade Bounty' plots.

During the 3 years of study, terbacil applied with or without caneburning herbicides provided the best weed control for these three raspberry cultivars, consistently exceeding 77\% (Tables 1-3). In 2010, weed control from oxyfluorfen alone was similar to carfentrazone or terbacil alone at 43 DAT in 'Meeker' (Table 1). Oxyfluorfen performance was poorer than terbacil by 63 DAT.

Table 4. Primocane length of 'Meeker' and 'Coho' red raspberry throughout the growing season in the commercial field trial in 2010.

\begin{tabular}{|c|c|c|c|c|c|c|c|c|}
\hline & \multirow{2}{*}{ Treatment ${ }^{2}$} & \multicolumn{7}{|c|}{ Days after treatment } \\
\hline & & 43 & 63 & 80 & 92 & 105 & 121 & 138 \\
\hline \multirow[t]{5}{*}{ Meeker } & Carfentrazone & $45.0 \mathrm{~b}^{\mathrm{y}}$ & $103.8 \mathrm{~b}$ & $156.2 \mathrm{ab}$ & $180.1 \mathrm{a}$ & $199.8 \mathrm{ab}$ & $213.3 \mathrm{~b}$ & $238.5 \mathrm{ab}$ \\
\hline & Terbacil & $61.6 \mathrm{a}$ & $119.4 \mathrm{a}$ & $165.6 \mathrm{a}$ & $184.2 \mathrm{a}$ & $205.9 \mathrm{a}$ & $229.3 \mathrm{a}$ & $250.0 \mathrm{a}$ \\
\hline & Carfentrazone + terbacil & $46.9 \mathrm{~b}$ & $107.0 \mathrm{~b}$ & $158.6 \mathrm{ab}$ & $184.6 \mathrm{a}$ & $201.9 \mathrm{a}$ & $225.7 \mathrm{ab}$ & $246.3 \mathrm{a}$ \\
\hline & Oxyfluorfen + terbacil & $29.4 \mathrm{c}$ & $85.8 \mathrm{~d}$ & $143.4 \mathrm{c}$ & $168.4 \mathrm{~b}$ & $188.2 \mathrm{~b}$ & $214.6 \mathrm{ab}$ & $228.8 \mathrm{~b}$ \\
\hline & Nontreated & $64.1 \mathrm{a}$ & $122.7 \mathrm{a}$ & $160.7 \mathrm{ab}$ & $187.3 \mathrm{a}$ & $204.0 \mathrm{a}$ & $225.8 \mathrm{ab}$ & $246.4 \mathrm{a}$ \\
\hline & Terbacil & $34.7 \mathrm{a}$ & $70.2 \mathrm{a}$ & $118.9 \mathrm{a}$ & $152.7 \mathrm{a}$ & $178.5 \mathrm{a}$ & $198.7 \mathrm{a}$ & $210.5 \mathrm{a}$ \\
\hline & Carfentrazone + terbacil & $29.8 \mathrm{~b}$ & $70.7 \mathrm{a}$ & $116.1 \mathrm{a}$ & $151.5 \mathrm{a}$ & $173.5 \mathrm{a}$ & $187.9 \mathrm{ab}$ & $201.9 \mathrm{ab}$ \\
\hline & Oxyfluorfen + terbacil & $20.4 \mathrm{~d}$ & $63.9 \mathrm{ab}$ & $115.0 \mathrm{ab}$ & $149.7 \mathrm{a}$ & $174.7 \mathrm{a}$ & $192.9 \mathrm{ab}$ & $210.7 \mathrm{a}$ \\
\hline & Nontreated & $37.9 \mathrm{a}$ & $72.6 \mathrm{a}$ & $110.7 \mathrm{ab}$ & $133.3 \mathrm{~b}$ & $145.9 \mathrm{~b}$ & $160.4 \mathrm{c}$ & $173.7 \mathrm{c}$ \\
\hline
\end{tabular}

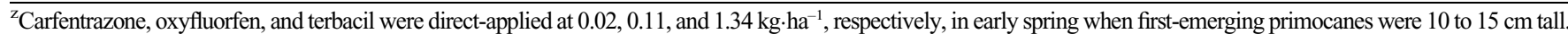

${ }^{\mathrm{y}}$ Cultivar means in each measurement date followed by the same letter are not significantly different based on Tukey's honestly significant difference method $(P \leq 0.05)$.

Table 5. Primocane length of 'Meeker' and 'Cascade Bounty' red raspberry throughout the growing season in the commercial field trial in 2011.

\begin{tabular}{|c|c|c|c|c|c|c|c|c|c|}
\hline & & \multicolumn{8}{|c|}{ Days after treatment } \\
\hline & & 33 & 47 & 61 & 78 & 90 & 103 & 117 & 132 \\
\hline Meeker & Carfentrazone & $23.1 \mathrm{c}^{\mathrm{y}}$ & $50.3 \mathrm{c}$ & $101.0 \mathrm{c}$ & $162.8 \mathrm{a}$ & $188.9 \mathrm{a}$ & $209.5 \mathrm{a}$ & $229.1 \mathrm{ab}$ & $250.7 \mathrm{a}$ \\
\hline & Terbacil & $39.4 \mathrm{~b}$ & $70.5 \mathrm{~b}$ & $118.7 \mathrm{ab}$ & $166.1 \mathrm{a}$ & $191.4 \mathrm{a}$ & $209.1 \mathrm{a}$ & $220.5 \mathrm{ab}$ & $2387 \mathrm{a}$ \\
\hline \multirow{5}{*}{ Cascade Bounty } & Carfentrazone + terbacil & $23.9 \mathrm{c}$ & $53.6 \mathrm{c}$ & $107.2 \mathrm{bc}$ & $168.1 \mathrm{a}$ & $184.3 \mathrm{a}$ & $218.0 \mathrm{a}$ & $234.0 \mathrm{ab}$ & $257.0 \mathrm{a}$ \\
\hline & Oxyfluorfen + terbacil & $11.5 \mathrm{~d}$ & $40.5 \mathrm{~d}$ & $93.9 \mathrm{c}$ & $158.9 \mathrm{a}$ & $188.4 \mathrm{a}$ & $209.5 \mathrm{a}$ & $224.7 \mathrm{ab}$ & $251.8 \mathrm{a}$ \\
\hline & Nontreated & $52.1 \mathrm{a}$ & $84.8 \mathrm{a}$ & $132.0 \mathrm{a}$ & $173.1 \mathrm{a}$ & $192.9 \mathrm{a}$ & 202.9 a & $212.7 \mathrm{~b}$ & $249.1 \mathrm{a}$ \\
\hline & Terbacil & $48.0 \mathrm{~b}$ & $88.0 \mathrm{~b}$ & $122.1 \mathrm{ab}$ & $157.6 \mathrm{a}$ & $177.3 \mathrm{a}$ & $197.2 \mathrm{a}$ & $207.3 \mathrm{a}$ & $208.0 \mathrm{a}$ \\
\hline & Nontreated & $54 . \mathrm{a}$ & $99.0 \mathrm{a}$ & $130.1 \mathrm{a}$ & $169.7 \mathrm{a}$ & $191.3 \mathrm{a}$ & $206.6 \mathrm{a}$ & $214.6 \mathrm{a}$ & $222.4 \mathrm{a}$ \\
\hline
\end{tabular}

${ }^{\mathrm{z}}$ Carfentrazone, oxyfluorfen, and terbacil were direct-applied at $0.02,0.11$, and $1.34 \mathrm{~kg} \cdot \mathrm{ha}^{-1}$, respectively, in early spring when first-emerging primocanes were 10 to $15 \mathrm{~cm}$ tall.

${ }^{\mathrm{y}}$ Cultivar means in each measurement date followed by the same letter are not significantly different based on Tukey's honestly significant difference method $(P \leq 0.05)$.

Table 6. Primocane length of 'Meeker' and 'Cascade Bounty' red raspberry throughout the growing season in the commercial field trial in 2012.

\begin{tabular}{|c|c|c|c|c|c|c|}
\hline & \multirow{2}{*}{ Treatment ${ }^{z}$} & \multicolumn{5}{|c|}{ Days after treatment } \\
\hline & & 33 & 47 & 68 & 87 & 102 \\
\hline \multirow[t]{5}{*}{ Meeker } & Carfentrazone & $35.1 \mathrm{~cd}^{\mathrm{y}}$ & $66.2 \mathrm{de}$ & $126.9 \mathrm{c}$ & $163.8 \mathrm{a}$ & $184.4 \mathrm{~b}$ \\
\hline & Terbacil & $66.4 \mathrm{~b}$ & $97.6 \mathrm{~b}$ & $143.32 \mathrm{abc}$ & $174.5 \mathrm{a}$ & $197.7 \mathrm{ab}$ \\
\hline & Carfentrazone + terbacil & $38.8 \mathrm{c}$ & $75.0 \mathrm{~cd}$ & $139.7 \mathrm{bc}$ & $164.6 \mathrm{a}$ & $202.0 \mathrm{ab}$ \\
\hline & Oxyfluorfen + terbacil & $28.1 \mathrm{~d}$ & $60.6 \mathrm{e}$ & $126.1 \mathrm{c}$ & $176.2 \mathrm{a}$ & $185.1 \mathrm{~b}$ \\
\hline & Nontreated & $81.7 \mathrm{a}$ & $116.6 \mathrm{a}$ & $160.5 \mathrm{a}$ & $184.2 \mathrm{a}$ & $213.3 \mathrm{a}$ \\
\hline & Terbacil & $81.0 \mathrm{a}$ & $112.0 \mathrm{ab}$ & $158.5 \mathrm{ab}$ & $180.1 \mathrm{ab}$ & $187.3 \mathrm{~b}$ \\
\hline & Nontreated & $89.5 \mathrm{a}$ & $123.6 \mathrm{a}$ & $173.7 \mathrm{a}$ & $198.8 \mathrm{a}$ & $214.5 \mathrm{a}$ \\
\hline
\end{tabular}

${ }^{\mathrm{z}}$ Carfentrazone, oxyfluorfen, and terbacil were direct-applied at $0.02,0.11$, and $1.34 \mathrm{~kg} \cdot \mathrm{ha}^{-1}$, respectively, in early spring when first-emerging primocanes were 10 to $15 \mathrm{~cm}$ tall.

${ }^{\mathrm{y}}$ Cultivar means in each measurement date followed by the same letter are not significantly different based on Tukey's honestly significant difference method $(P \leq 0.05)$. 

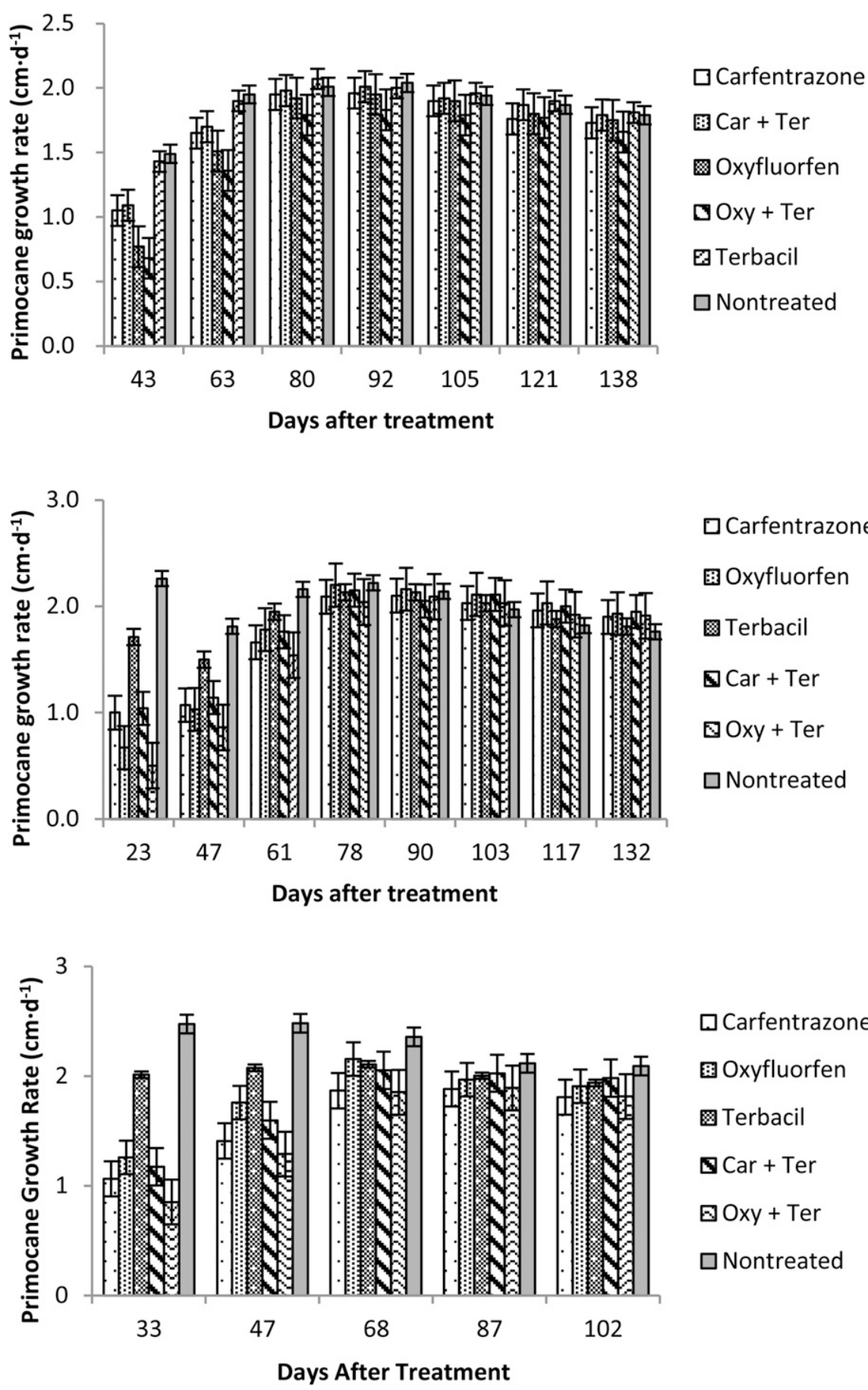

Fig. 1. 'Meeker' red raspberry primocane growth rate $\left(\mathrm{cm} \cdot \mathrm{d}^{-1}\right)$ in the commercial field trial $(\mathbf{A}, 2010 ; \mathbf{B}$ 2011; C, 2012). Carfentrazone, oxyfluorfen, and terbacil were direct-applied at $0.02,0.11$, and 1.34 $\mathrm{kg} \cdot \mathrm{ha}^{-1}$, respectively, when first-emerging primocanes were 10 to $15 \mathrm{~cm}$ tall. Standard error bars are provided.

By 138 DAT, weed control was only $60 \%$ and $70 \%$ with carfentrazone and oxyfluorfen, respectively, whereas tank mixtures with terbacil provided $89 \%$ and $95 \%$ weed control, respectively. In 'Coho', weed control with carfentrazone and oxyfluorfen alone was poor $(51 \%$ and $52 \%$ by 138 DAT, respectively). In 2011, weed control in 'Meeker' exceeded $90 \%$ throughout the season with terbacil applied alone or in mixture with carfentrazone or oxyfluorfen (Table 2). Weed control with carfentrazone and oxyfluorfen season. Caneburning herbicides applied to 'Cascade Bounty' provided generally comparable weed control to terbacil, although weed cover in nontreated plots was below $10 \%$ throughout the season (data not shown).

Owing to the interaction between treatment and measurement date for primocane length, data were analyzed separately for each cultivar on each date in each year. In 2010, nontreated 'Meeker' primocanes tended to be longer than most caneburned 'Meeker' primocanes at 63 DAT (Table 4). Carfentrazone with or without terbacil suppressed primocane growth until between 63 and 80 DAT, whereas oxyfluorfen used alone suppressed primocane growth until between 80 and 92 DAT. Oxyfluorfen + terbacil, however, suppressed primocane growth 7\% compared with carfentrazone + terbacil and noncaneburned raspberry at 138 DAT. 'Coho' primocane length in 2010 was reduced by all caneburning treatments at 43 DAT. Carfentrazone applied alone tended to be more suppressive to 'Coho' primocanes than other treatments at most measurement dates. Except for 'Coho' treated with carfentrazone alone, caneburned 'Coho' primocane length exceeded that of noncaneburned primocanes at 92 DAT. All treatments increased 'Coho' primocane length $7 \%$ to $18 \%$ at 138 DAT compared with nontreated 'Coho', although primocanes in plots treated with carfentrazone alone did not differ from nontreated plots. In 2011, 'Meeker' primocanes were suppressed by all herbicide treatments except terbacil alone at 61 DAT (Table 5). Oxyfluorfen applied alone or mixed with terbacil suppressed primocane regrowth more than any other treatment through 47 DAT, but primocane length did not differ among treatments by 132 DAT. In 2011, 'Cascade Bounty' primocane length was suppressed by all treatments until between 61 and 78 DAT, with oxyfluorfen reducing primocane regrowth the most. From 78 DAT to 132 DAT, there were no differences in primocane length among treatments. In 2012 'Meeker', both caneburning herbicides mixed with terbacil suppressed primocane regrowth through 68 DAT (Table 6). Oxyfluorfen applied alone suppressed primocane growth through 47 DAT, whereas oxyfluorfen + terbacil and carfentrazone alone provided primocane suppression through 102 DAT. In 2012, caneburning herbicides generally suppressed 'Cascade Bounty' primocane regrowth through 102 DAT.

Although 'Meeker' primocane diameter was rarely affected by herbicide treatments in 2010, primocanes of nontreated 'Coho' were generally thinner $(7.8 \mathrm{~mm})$ than treated primocanes (from 8.6 to $9.9 \mathrm{~mm}$ ) at 80 DAT. Herbicide treatments increased 'Coho' primocane diameter from $9 \%$ to $23 \%$ compared with nontreated raspberry, although oxyfluorfen + terbacil increased diameter the most. In 2011, primocane diameter of 'Meeker' was reduced by caneburning only at 33 DAT (from 7.1 to $7.4 \mathrm{~mm}$, compared with $8.6 \mathrm{~mm}$ for nontreated primocanes), after which diameter did not differ among treatments until 117 DAT. At 117 and 132 
DAT, nontreated primocanes were thinner (9.9 and $9.8 \mathrm{~mm}$, respectively) than when treated with oxyfluorfen alone $(11.1 \mathrm{~mm})$. Primocane diameter of 'Cascade Bounty' was similar in all seasons after carfentrazone and terbacil treatments, ranging from $8.8 \mathrm{~mm}$ at 33 DAT to $11.9 \mathrm{~mm}$ at 132 DAT. In 2012, 'Meeker' primocane diameter was reduced
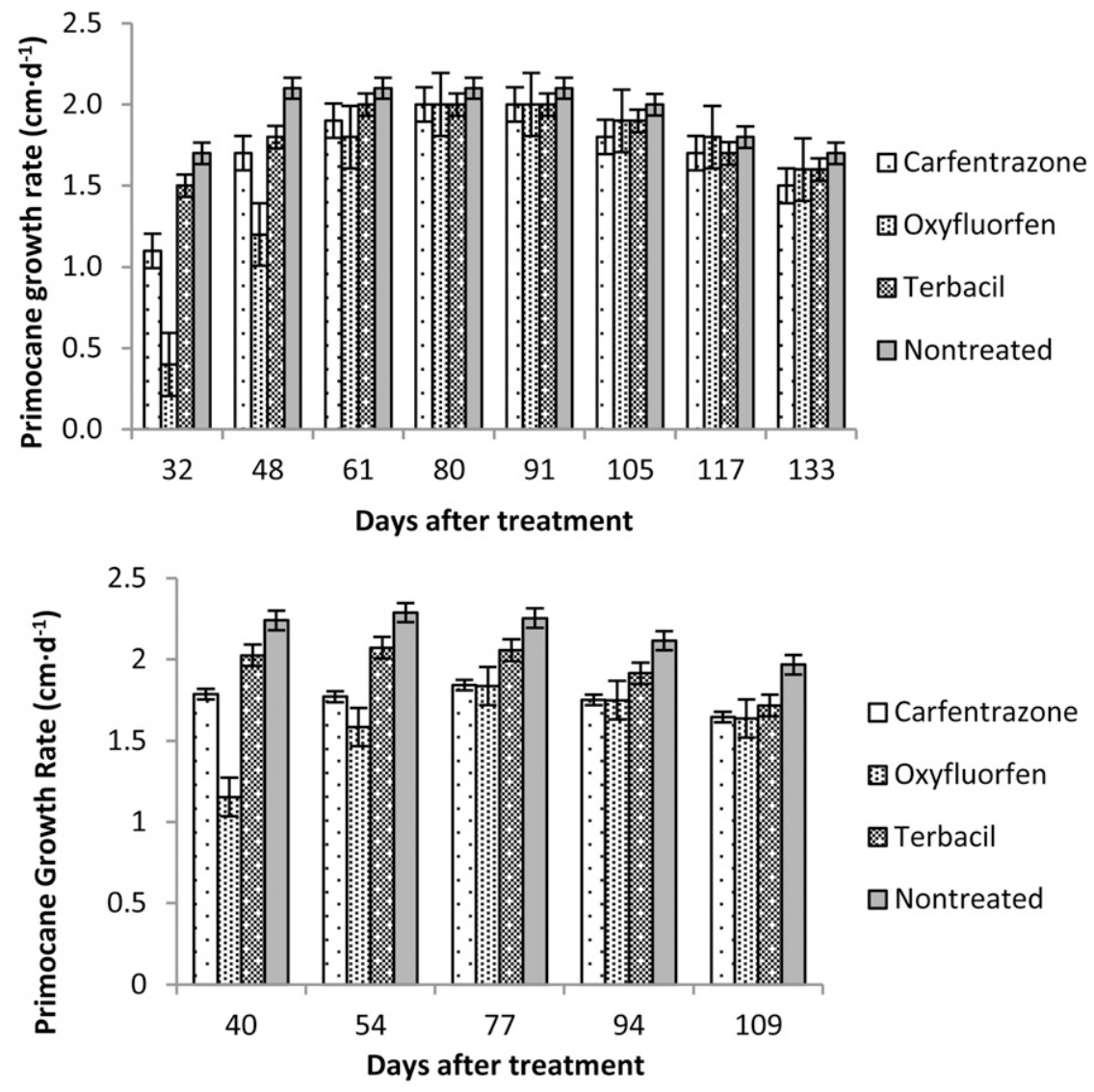

Fig. 2. 'Cascade Bounty' red raspberry primocane growth rate $\left(\mathrm{cm} \cdot \mathrm{d}^{-1}\right)$ in the commercial field trial $(\mathbf{A}, 2011$; B, 2012). Carfentrazone, oxyfluorfen, and terbacil were direct-applied at $0.02,0.11$, and $1.34 \mathrm{~kg} \cdot \mathrm{ha}^{-1}$, respectively, when first-emerging primocanes were 10 to $15 \mathrm{~cm}$ tall. Standard error bars are provided.

by all treatments at 46 DAT but not at 60 DAT or beyond. Although oxyfluorfen suppressed primocane diameter at 33 DAT $(7.4 \mathrm{~mm})$ compared with nontreated raspberry $(9.8 \mathrm{~mm})$, primocane diameter increased rapidly from 47 DAT until the end of the season, resulting in thicker primocanes $(13.5 \mathrm{~mm})$ than treatment with either carfentrazone $(11.9 \mathrm{~mm})$ or terbacil $(11.4 \mathrm{~mm})$. No treatment suppressed 'Cascade Bounty' primocane diameter at any time during 2012.

'Meeker' primocane growth rate was reduced by caneburning until between 63 and 80 DAT in 2010, between 61 and 78 DAT in 2011, and between 68 and 87 DAT in 2012, after which growth rate did not greatly differ by treatment (Figs. 1A-C). 'Coho' primocane growth rate was reduced by caneburning until between 43 and 63 DAT in 2010 (data not shown). 'Cascade Bounty' growth rate was reduced by oxyfluorfen until between 61 and 80 DAT in 2011, whereas carfentrazone and terbacil reduced primocane growth rate only until between 48 and 61 DAT (Fig. 2A). Oxyfluorfen reduced 'Cascade Bounty' primocane growth rate more than carfentrazone, but by 80 DAT, primocane growth rate was comparable among treatments for the remainder of the season. In 2012, 'Cascade Bounty' primocane growth rate was reduced by all treatments through 109 DAT (Fig. 2B).

Although 'Meeker' berry yield was not increased by caneburning in any single year (data not shown), caneburning treatments increased the 3 -year average yield by $29 \%$ to $47 \%$ compared with nontreated raspberry, whereas terbacil applied alone increased 3 -year yield by $22 \%$ (Table 7). Conversely, berry yield of 'Coho' (2010 only) or 'Cascade Bounty' (1- or 2-year average) was not significantly increased by herbicide treatment.

Table 7. Total red raspberry fruit yield in the commercial field trials in 2010, 2011, and 2012.

\begin{tabular}{|c|c|c|c|c|}
\hline & & Meeker & Coho & Cascade Bounty \\
\hline Carfentrazone & 0.02 & $7,784 a b^{y}$ & 4,099 & 9,212 \\
\hline Terbacil & 1.34 & $7,384 \mathrm{~b}$ & 4,638 & 9,187 \\
\hline Carfentrazone + terbacil & $0.02+1.34$ & $8,859 \mathrm{a}$ & 4,449 & - \\
\hline Oxyfluorfen + terbacil & $0.11+1.34$ & $8,601 \mathrm{a}$ & 4,887 & - \\
\hline Nontreated & _ & $6,043 \mathrm{c}$ & 3,646 & 8,474 \\
\hline
\end{tabular}

${ }^{\mathrm{z}}$ Herbicides were direct-applied in early spring when first-emerging primocanes were 10 to $15 \mathrm{~cm}$ tall.

${ }^{y}$ Cultivar means in each measurement date followed by the same letter, or not followed by a letter, are not significantly different based on Tukey's honestly significant difference method $(P \leq 0.05)$.

Table 8. Primocane length of 'Meeker' and 'Cascade Bounty' red raspberry throughout the growing season in the research field trial in 2010.

\begin{tabular}{|c|c|c|c|c|c|c|c|c|}
\hline \multirow[b]{3}{*}{ Cultivar } & \multirow[b]{3}{*}{ Treatment $^{z}$} & \multicolumn{7}{|c|}{ Days after treatment } \\
\hline & & 31 & 50 & 70 & 80 & 94 & 102 & 117 \\
\hline & & \multicolumn{7}{|c|}{ Primocane length $(\mathrm{cm})$} \\
\hline \multirow[t]{2}{*}{ Meeker } & Carfentrazone & $26.4 b^{y}$ & $64.6 \mathrm{~b}$ & $132.5 \mathrm{~b}$ & $153.3 \mathrm{~b}$ & $181.2 \mathrm{a}$ & $212.0 \mathrm{a}$ & 232.3 \\
\hline & Nontreated & $57.6 \mathrm{a}$ & $97.4 \mathrm{a}$ & $149.3 \mathrm{a}$ & $168.6 \mathrm{a}$ & $186.5 \mathrm{a}$ & $220.0 \mathrm{a}$ & 240.2 \\
\hline \multirow[t]{3}{*}{ Cascade Bounty } & Carfentrazone & $31.5 \mathrm{~b}$ & $68.1 \mathrm{~b}$ & $123.6 \mathrm{~b}$ & $141.0 \mathrm{~b}$ & $161.0 \mathrm{~b}$ & $182.8 \mathrm{ab}$ & 202.1 \\
\hline & Oxyfluorfen & $22.0 \mathrm{c}$ & $53.7 \mathrm{c}$ & $110.3 \mathrm{c}$ & $127.5 \mathrm{c}$ & $149.9 \mathrm{~b}$ & $168.1 \mathrm{~b}$ & 190.0 \\
\hline & Nontreated & $64.0 \mathrm{a}$ & $97.5 \mathrm{a}$ & $141.5 \mathrm{a}$ & $158.8 \mathrm{a}$ & $175.0 \mathrm{a}$ & $190.2 \mathrm{a}$ & 205.0 \\
\hline
\end{tabular}

${ }^{\mathrm{z}}$ Carfentrazone and oxyfluorfen were direct-applied at 0.02 and $0.11 \mathrm{~kg} \cdot \mathrm{ha}^{-1}$, respectively, in early spring when first-emerging primocanes were 10 to $15 \mathrm{~cm}$ tall. ${ }^{\mathrm{y}}$ Means in each measurement date followed by the same letter, or not followed by a letter, are not significantly different based on Tukey's honestly significant difference method $(P \leq 0.05)$. 
Research field trial. 'Meeker' primocane length was reduced by oxyfluorfen until between 70 and 80 DAT, by carfentrazone until between 80 and 94 DAT in 2010 (Table 8), and by both herbicides until between 65 and 80 DAT in 2011 (Table 9). In 2012, oxyfluorfen reduced primocane regrowth until between 97 and 115 DAT, whereas carfentrazone suppressed regrowth until between 52 and 67 DAT (Table 10). 'Cascade Bounty' primocanes in 2010 were shortened by oxyfluorfen until between 102 and 117 DAT and by carfentrazone until between 94 and 102 DAT (Table 8). In 2011, oxyfluorfen suppressed 'Cascade Bounty' primocane length until between 108 and 121 DAT and carfentrazone suppressed primocane length until between 52 and 65 DAT (Table 9). In 2012, caneburning herbicides shortened primocanes through 115 DAT (Table 10). 'Cascade Bounty' primocanes tended to be shorter than 'Meeker' at all measurements in all 3 years, except at 31 DAT in 2010 and 35 DAT in 2011 and 2012, indicating that cultivars were consistent as to when primocane regrowth after treatment began in each year.

Although initially thinner than nontreated 'Meeker' primocanes in 2010, oxyfluorfentreated primocanes were thicker at $70 \mathrm{DAT}$ and beyond. By $50 \mathrm{DAT}$, primocane diameter was the same for raspberries treated with either carfentrazone $(9.6 \mathrm{~mm})$ or oxyfluorfen $(9.5 \mathrm{~mm})$. At $117 \mathrm{DAT}$, primocanes were 11.1 and $11.4 \mathrm{~mm}$ in diameter for carfentrazone and oxyfluorfen, respectively, compared with $9.8 \mathrm{~mm}$ for nontreated primocanes. Primocane diameter of 'Cascade Bounty' was reduced by oxyfluorfen at 31 DAT $(7.3 \mathrm{~mm})$ compared with carfentrazone treatment $(8.4 \mathrm{~mm})$ or nontreated primocanes $(8.7 \mathrm{~mm})$, but by $50 \mathrm{DAT}$ and for the rest of the season, primocane diameter did not differ among treatments. In 2011, whereas primocane diameter of both cultivars was reduced by oxyfluorfen at 35 DAT, 'Cascade Bounty' primocane diameter was also reduced by carfentrazone. Primocane diameter did not differ among treatments for 'Meeker' until 136 DAT, at which time carfentrazonetreated primocanes were $11.4 \mathrm{~mm}$ compared with $10.3 \mathrm{~mm}$ in nontreated raspberry. In 2012, 'Cascade Bounty' primocane diameter was only reduced by carfentrazone at 35 DAT, whereas diameter of caneburned 'Meeker' primocanes exceeded that of nontreated primocanes by $1.5 \mathrm{~mm}$ or less at 67 , 82, and 125 DAT.

Caneburning slowed 'Meeker' primocane growth rate until between 50 and 70 DAT in 2010, between 52 and 65 DAT in 2011, and between 52 and 67 DAT in 2012, whereas caneburning reduced primocane growth rate of 'Cascade Bounty' until between 94 and 102 DAT in 2010, between 80 and 94 DAT in 2011, and between 97 and 115 DAT in 2011 (Fig. 3A-C). 'Meeker' primocane growth rate did not greatly differ whether treated by carfentrazone and oxyfluorfen in any year, but oxyfluorfen suppressed the growth rate of 'Cascade Bounty' primocanes about $14 \mathrm{~d}$ longer than did carfentrazone in 2010 and 2011.

Raspberry yield differed by year, but there was no interaction between cultivar and treatment or three-way interactions (cultivar $x$ treatment $\times$ year). Therefore, yield data were separately analyzed by treatment and cultivar in each year. When averaged across cultivars for all 3 years, carfentrazone and oxyfluorfen increased berry yield by $22 \%$ and $30 \%$, respectively (Table 11). 'Meeker' berry yield was only increased by caneburning in 2011, whereas 'Cascade Bounty' was unaffected by caneburning in any year. However, there was a trend in all years toward increased berry yield resulting from caneburning for both cultivars. Although not statistically significant, 3-year average 'Cascade Bounty' yield was numerically $30 \%$ and $35 \%$ greater after treatment with carfentrazone and oxyfluorfen compared with nontreated 'Cascade Bounty', respectively, whereas 3-year average 'Meeker' yield was $16 \%$ and $25 \%$ higher, respectively. When combined across treatments, 'Meeker' produced greater yield than 'Cascade Bounty' in all 3 years, significantly so in 2010 and 2011, resulting in a 3-year average of $6888 \mathrm{~kg} \cdot \mathrm{ha}^{-1}$ for 'Meeker' compared with $5640 \mathrm{~kg} \cdot \mathrm{ha}^{-1}$ for 'Cascade Bounty' (data not shown). Average fruit yield was greatest in 2010 and least in 2011 (7160 and $5188 \mathrm{~kg} \cdot \mathrm{ha}^{-1}$, respectively).

\section{Discussion}

Carfentrazone and oxyfluorfen are both protoporphyrinogen oxidase (PPO or Protox) inhibitors that provide substantial defoliation of broadleaf plants and do not translocate from leaves to roots (Shaner, 2014). As such, they generally provide a similar level of postemergence weed control with only transitory injury to treated foliage of a perennial crop such as raspberry. Oxyfluorfen, however, possesses an average soil half-life of $35 \mathrm{~d}$, compared with only a few hours with carfentrazone (Shaner, 2014), so oxyfluorfen has a greater potential for preemergence weed control and has been shown to slow raspberry primocane regrowth longer than carfentrazone (Miller et al., 2008). These two factors deserve attention in light of the results presented here.

Weed control from carfentrazone or oxyfluorfen differed only rarely, except in 2012, when weed control in 'Meeker' plots was

Table 9. Primocane length of 'Meeker' and 'Cascade Bounty' red raspberry throughout the growing season in the research field trial in 2011.

\begin{tabular}{|c|c|c|c|c|c|c|c|c|c|}
\hline \multirow[b]{3}{*}{ Cultivar } & \multirow[b]{3}{*}{ Treatment ${ }^{z}$} & \multicolumn{8}{|c|}{ Days after treatment } \\
\hline & & 35 & 52 & 65 & 80 & 94 & 108 & 121 & 136 \\
\hline & & \multicolumn{8}{|c|}{ Primocane length $(\mathrm{cm})$} \\
\hline \multirow[t]{3}{*}{ Meeker } & Carfentrazone & $29.3 \mathrm{~b}^{\mathrm{y}}$ & $74.1 \mathrm{~b}$ & $122.5 \mathrm{~b}$ & $167.4 \mathrm{a}$ & $200.4 \mathrm{a}$ & $223.3 \mathrm{a}$ & 247.8 & 276.0 \\
\hline & Oxyfluorfen & $26.7 \mathrm{~b}$ & $71.3 \mathrm{~b}$ & $120.1 \mathrm{~b}$ & $165.0 \mathrm{a}$ & $198.5 \mathrm{a}$ & $228.2 \mathrm{a}$ & 252.8 & 278.0 \\
\hline & Nontreated & $50.6 \mathrm{a}$ & $94.7 \mathrm{a}$ & $135.2 \mathrm{a}$ & $174.0 \mathrm{a}$ & $202.4 \mathrm{a}$ & $218.2 \mathrm{a}$ & 254.8 & 274.5 \\
\hline \multirow[t]{3}{*}{ Cascade Bounty } & Carfentrazone & $36.0 \mathrm{~b}$ & $75.4 \mathrm{~b}$ & $112.5 \mathrm{a}$ & $153.6 \mathrm{ab}$ & $184.7 \mathrm{ab}$ & $205.0 \mathrm{ab}$ & 223.7 & 237.2 \\
\hline & Oxyfluorfen & $28.8 \mathrm{c}$ & $65.4 \mathrm{c}$ & $100.7 \mathrm{~b}$ & $143.5 \mathrm{~b}$ & $173.7 \mathrm{~b}$ & $198.4 \mathrm{~b}$ & 216.6 & 229.4 \\
\hline & Nontreated & $50.0 \mathrm{a}$ & $87.3 \mathrm{a}$ & $121.4 \mathrm{a}$ & $160.2 \mathrm{a}$ & $192.6 \mathrm{a}$ & $216.8 \mathrm{a}$ & 231.4 & 240.8 \\
\hline
\end{tabular}

${ }^{\mathrm{z}}$ Carfentrazone and oxyfluorfen were direct-applied at 0.02 and $0.11 \mathrm{~kg} \cdot \mathrm{ha}^{-1}$, respectively, in early spring when first-emerging primocanes were 10 to $15 \mathrm{~cm}$ tall. ${ }^{\mathrm{y}}$ Means in each measurement date followed by the same letter, or not followed by a letter, are not significantly different based on Tukey's honestly significant difference method $(P \leq 0.05)$.

Table 10. Primocane length of 'Meeker' and 'Cascade Bounty' red raspberry throughout the growing season in the research field trial in 2012

\begin{tabular}{|c|c|c|c|c|c|c|c|}
\hline \multirow[b]{3}{*}{ Cultivar } & \multirow[b]{3}{*}{ Treatment ${ }^{\mathrm{z}}$} & \multicolumn{6}{|c|}{ Days after treatment } \\
\hline & & 35 & 52 & 67 & 82 & 97 & 115 \\
\hline & & \multicolumn{6}{|c|}{ Primocane length $(\mathrm{cm})$} \\
\hline \multirow[t]{3}{*}{ Meeker } & Carfentrazone & $37.4 \mathrm{~b}^{\mathrm{y}}$ & $87.6 \mathrm{~b}$ & $141.7 \mathrm{ab}$ & $180.3 \mathrm{ab}$ & $207.6 \mathrm{ab}$ & $236.1 \mathrm{a}$ \\
\hline & Oxyfluorfen & $35.9 \mathrm{~b}$ & $80.3 \mathrm{~b}$ & $128.9 \mathrm{~b}$ & $165.7 \mathrm{~b}$ & $190.7 \mathrm{~b}$ & $231.8 \mathrm{a}$ \\
\hline & Nontreated & $65.6 \mathrm{a}$ & $106.7 \mathrm{a}$ & $150.8 \mathrm{a}$ & $184.0 \mathrm{a}$ & $219.0 \mathrm{a}$ & $249.7 \mathrm{a}$ \\
\hline \multirow[t]{3}{*}{ Cascade Bounty } & Carfentrazone & $37.6 \mathrm{~b}$ & $75.8 \mathrm{~b}$ & $112.7 \mathrm{~b}$ & $135.3 \mathrm{~b}$ & $154.0 \mathrm{~b}$ & $181.6 \mathrm{~b}$ \\
\hline & Oxyfluorfen & $38.2 \mathrm{~b}$ & $80.1 \mathrm{~b}$ & $188.2 \mathrm{~b}$ & $145.4 \mathrm{~b}$ & $165.6 \mathrm{~b}$ & $196.2 \mathrm{~b}$ \\
\hline & Nontreated & $79.9 \mathrm{a}$ & $114.4 \mathrm{a}$ & $144.4 \mathrm{a}$ & $173.8 \mathrm{a}$ & $196.7 \mathrm{a}$ & $217.9 \mathrm{a}$ \\
\hline
\end{tabular}

${ }^{\mathrm{z}}$ Carfentrazone and oxyfluorfen were direct-applied at 0.02 and $0.11 \mathrm{~kg} \cdot \mathrm{ha}^{-1}$, respectively, in early spring when first-emerging primocanes were 10 to $15 \mathrm{~cm}$ tall.

${ }^{\mathrm{y}}$ Means in each measurement date followed by the same letter are not significantly different based on Tukey's honestly significant difference method $(P \leq 0.05)$. 
poor from the outset (Tables 1-3), indicating that these herbicides provided comparable control of the weed species present in these plots. Still, season-long weed control was not possible with either caneburning herbicide used alone, particularly if the same herbicide program was followed for multiple years. For example, without application of a residual
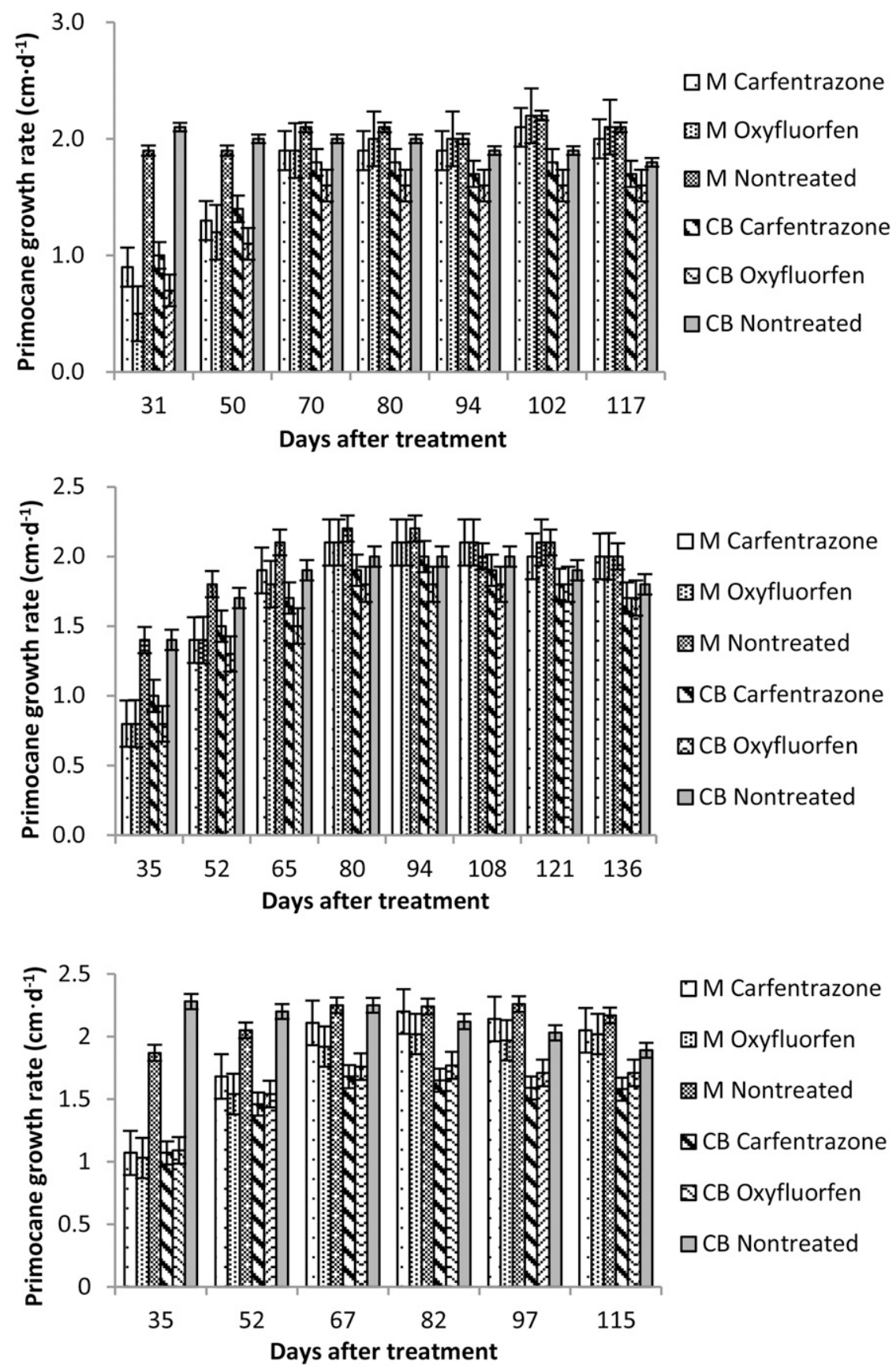

Fig. 3. Primocane growth rate $\left(\mathrm{cm} \cdot \mathrm{d}^{-1}\right)$ in the research field trial $(\mathbf{A}, 2010 ; \mathbf{B}, 2011 ; \mathbf{C}, 2012)$. Carfentrazone and oxyfluorfen were direct-applied at 0.02 and $0.11 \mathrm{~kg} \cdot \mathrm{ha}^{-1}$, respectively, when first-emerging primocanes were 10 to $15 \mathrm{~cm}$ tall. $\mathrm{M}=$ 'Meeker'; $\mathrm{CB}=$ 'Cascade Bounty'. Standard error bars are provided.

herbicide such as terbacil, with a soil half-life of $120 \mathrm{~d}$ (Shaner, 2014), weed control fell below $70 \%$ in the commercial 'Meeker' field more quickly each year: at 138 DAT in 2010, at 71 DAT in 2011, and at 47 DAT in 2012. This contrasts with greater than $80 \%$ control at the end of each season when terbacil was applied. Therefore, the combination or sequential application of residual and caneburning herbicides is recommended to provide season-long weed control and to reduce the likelihood of weed population increases from year to year.

Oxyfluorfen provided longer suppression of primocane growth than did carfentrazone, particularly in 'Cascade Bounty' but also to a lesser extent in 'Meeker'. 'Meeker' primocanes treated with oxyfluorfen were shorter than nontreated primocanes for an average of $70 \mathrm{~d}$ in these two trials, whereas 'Cascade Bounty' primocanes were delayed for an average of $98 \mathrm{~d}$ (Tables 4-6 and 8-10). Oxyfluorfen reduced 'Cascade Bounty' primocane growth rate $17 \%$ to $46 \%$ more than carfentrazone for about the first 45 DAT in 2011 and 2012 in the commercial field trial (Fig. $2 \mathrm{~A}$ and $\mathrm{B}$ ) and $\approx 33 \%$ to $40 \%$ more at 23 to 43 DAT, respectively, for 'Meeker' (Fig. 1A and B). Reduced primocane growth rates with oxyfluorfen were not universal, however, as 'Meeker' growth was $20 \%$ lower with carfentrazone than with oxyfluorfen at 47 DAT in the 2012 commercial field trial (Fig. 1C), and the two herbicides did not statistically differ in their effect on primocane growth rate for either cultivar during any year in the research field trial (Fig. 3A-C).

It is interesting to note that caneburning did not improve raspberry yield in five of the six tested years for 'Meeker', or in any of the five tested years for 'Cascade Bounty' or the single year for 'Coho' (Tables 7 and 11). Despite this, oxyfluorfen improved 3-year 'Meeker' average yield by $43 \%$ from nontreated raspberry in the commercial field trial, compared with the $29 \%$ increase with carfentrazone. This effect was also observed with 'Meeker' in the research field trial $(30 \%$ increased yield with oxyfluorfen compared with $22 \%$ with carfentrazone) (Table 11). 'Cascade Bounty' yield did not significantly differ by year or in the 2- or 3-year average yield in the commercial and research field trials, respectively (Tables 8 and 11). So, while caneburning may only exert a modest effect on 'Meeker' yield in any given year, the cumulative effect over multiple years is an increase in marketable fruit. It also appears that the longer suppression of primocane growth

Table 11. Total red raspberry fruit yield in the research field trial in 2010, 2011, and 2012.

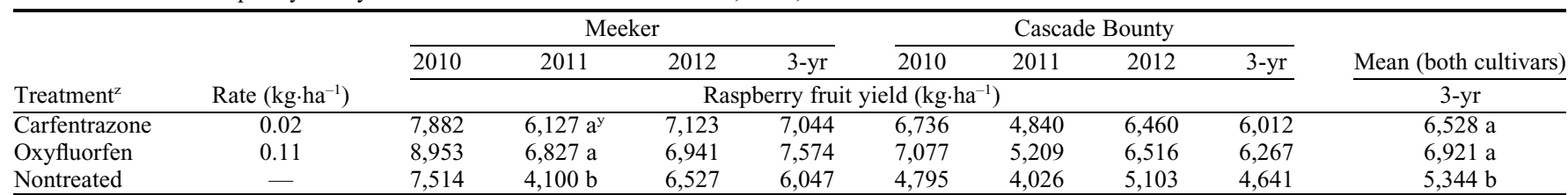

${ }^{\mathrm{z}}$ Herbicides were direct-applied in early spring when first-emerging primocanes were 10 to $15 \mathrm{~cm}$ tall.

${ }^{\mathrm{y}}$ Means in each measurement date followed by the same letter, or not followed by a letter, are not significantly different based on Tukey's honestly significant difference method $(P \leq 0.05)$. 
achieved by oxyfluorfen in 'Meeker' tended to provide greater yield benefit than treatment with carfentrazone, although it must be stressed that berry yield did not differ statistically between those two herbicides.

If 'Cascade Bounty' primocane growth was suppressed longer than 'Meeker' by caneburning, why did 'Cascade Bounty' not show a significant yield response? This probably is because of different growth habits of the two cultivars. Fernandez and Pritts (1994) demonstrated that raspberry plants store carbohydrates in roots during the winter, and they remobilize the carbon the following year to flowers/fruit or use it for plant growth depending on carbon availability from current-season photosynthesis. 'Cascade Bounty' primocanes were generally shorter (Tables 8-10) and thinner (data not shown) than 'Meeker', which could have reduced shading of floricanes and increased the photosynthetic efficiency of 'Cascade Bounty' during flowering/fruiting, even in the absence of caneburning. Primocane growth rate was lower for 'Cascade Bounty' than for 'Meeker' later in the growing season in the research field trial (Fig. 3A-C), whereas fruit load was $1400 \mathrm{~kg} \cdot \mathrm{ha}^{-1}$ less in nontreated 'Cascade Bounty' than it was in nontreated 'Meeker' (Table 11). Taken together, then, it is likely that 'Cascade Bounty' required far fewer carbohydrates for its vegetative and reproductive growth than did the more vigorous 'Meeker', and the quantity of stored and current-season carbohydrates was apparently adequate for 'Cascade Bounty' fruiting and primocane growth in the absence of caneburning. Differing yield according to cultivar vigor is in agreement with the observation that the greater yield responses to caneburning are found in cultivars with higher cane vigor (Norton, 1973). Fernandez and Pritts (1993) also suggested that raspberry genotypes may respond differently to light and temperature that can result in differential growth and yield. In the current study, 'Cascade Bounty', and perhaps 'Coho' as well, appear to be genotypes with a balanced primocane-floricane ratio and, therefore, did not benefit to the extent that 'Meeker' did from caneburning.

Not surprisingly, the first primocanes on nontreated raspberry cultivars in the current trials tended to be thicker than those produced on caneburned plants, but this difference was more transitory than the effects on primocane length. Owing to the brief effect of caneburning on primocane diameter, it appears that primocane length is a more important factor to consider than diameter when measuring raspberry response to caneburning.

Weed competition effects on raspberry yield were not as clear. Berries matured in a range from 80 to 130 DAT in the commercial field trial, a time when weed control was poor in 2011 and 2012, so it is tempting to conclude that weeds may have reduced raspberry yield in plots treated with caneburning herbicides alone. This conclusion is supported by the $22 \%$ increase in berry yield observed with terbacil applied alone, a treatment giving excellent weed control but exerting no significant effect on primocanes. However, the 'Meeker' 3-year average yield was maximized with oxyfluorfen used alone (43\% increase compared with nontreated raspberry) or with terbacil combination treatments (42\% to $47 \%$ increases) despite the wide disparity in weed control at harvest time resulting from these treatments. The increase in berry yield from terbacil alone was also significantly less than from oxyfluorfen alone or terbacil combinations. It therefore appears that primocane growth is the primary factor involved in 'Meeker' yield response to caneburning and that weed interference plays only a minor role.

Crandall (1977) suggested caneburning herbicides should be used only after consideration of raspberry plant vigor. Parts of the 'Coho' field displayed root rot symptoms in 2010 and yield was generally less than 'Meeker' that year (Table 7), indicating a low vigor in that planting. Application of caneburning herbicides did not appear to result in 'Coho' plant decline, however, based on initial growth of the cultivar before its removal in 2011. This contrasted with observations that carfentrazone applied to 'Meeker' plants displaying symptoms of root rot resulted in significant plant decline or death (Miller et al., 2008). Because other cultivars did not exhibit root rot symptoms, and because only 1 year of data are available for 'Coho', definitive conclusions of detrimental caneburning effects on lowervigor raspberry cannot be made from these trials.

In conclusion, data suggest that caneburning does not increase fruit production in all PNW red raspberry cultivars. Results from the trials reported here indicate that, although some grower caution is warranted when choosing to use caneburning herbicides, particularly for oxyfluorfen on 'Cascade Bounty', these products do not appear to cause lasting injury to healthy raspberry. Given the observed trend toward increased yield in the cultivars tested here, and given the other benefits previously attributed to caneburning, this practice will likely continue to be productively employed by PNW red raspberry growers.

\section{Literature Cited}

Alvarado-Raya, H.E., R.L. Darnell, and J.G. Williamson. 2007. Root to shoot relations in an annual raspberry (Rubus ideaeus L.) production system. HortScience 42:15591562.
Crandall, P.C. 1973. Dinitro cane burning at Vancouver, WA. Proc. West. WA Hort. Assoc. 60:101-105.

Crandall, P.C. 1977. Raspberry cane burning with dinitro sprays. Proc. West. WA. Hort. Assoc. 67:143-145.

Crandall, P.C. 1995. Bramble production: The management and marketing of raspberries and blackberries. Food Product Press, an imprint of the Haworth Press Inc., Binghamton, NY. p. 213.

Fernandez, G.E. and M.P. Pritts. 1993. Growth and source-sink relationship in 'Titan' red raspberry. Acta Hort. 352:151-157.

Fernandez, G.E. and M.P. Pritts. 1994. Growth, carbon acquisition and source-sink relationships in 'Titan' red raspberry. J. Amer. Soc. Hort. Sci. 119:1163-1168.

Fernandez, G.E. and M.P. Pritts. 1996. Carbon supply reduction has a minimal influence on current year's red raspberry (Rubus idaeus L.) fruit production. J. Amer. Soc. Hort. Sci. 121:473-477.

Freeman, J.A. and H.A. Daubeny. 1986. Effect of chemical removal of primocanes on several raspberry cultivars. Acta Hort. 183:215-222.

Howard, S.W. and J.S. Cameron. 1990. The applied aspects of cane burning with dinoseb alternatives. Proc. West. WA Hort. Assoc. 1990:108-109.

Howard, S.W., J.S. Cameron, and C.B. McConnell. 1989. Evaluation of cane burning materials for red raspberry. Acta Hort. 262:365-371.

Lawson, H.M. 1980. Recent research on cane vigor control in Scotland. Acta Hort. 112:151-156.

Lawson, H.M. and J.S. Wiseman. 1983. Techniques for the control of cane vigor in red raspberry in Scotland: Effects of timing and frequency of cane removal treatments on growth and yield in cv. 'Glen Clova'. J. Amer. Soc. Hort. Sci. 58:247-260.

Miller, T.W., S.F. Klauer, and M. Nicholson. 2008. Effects of primocane suppression programs on weed management and productivity of 'Meeker' red raspberry. Acta Hort. 777:267-274.

Norton, R.A. 1973. Red raspberry cane control research at Mount Vernon. Proc. West. WA. Hort. Assoc. 63:152-155.

Norton, R.A. 1974. Basal cane control of red raspberries-Four years results. Proc. Lower Mainland Hort. Improvement Assoc. 16:16-18.

Norton, R.A. 1980. Red raspberry primocane control research and practice in the Pacific Northwest. Acta Hort. 112:191-193.

Norton, R.A. 1981. Primocane control update-are we becoming careless? Proc. West. WA Hort. Assoc. 71:131-134.

Pritts, M.P. 2008. Primocane-fruiting raspberry production. HortScience 43:1640-1641.

Raspberry Industry Development Council. 2016. Fraser Valley processed red raspberry production. 28 Sept. 2016. <http://bcraspberries.com $>$.

Shaner, D.L. 2014. Herbicide Handbook. 10th ed. Weed Science Society of America, Champaign, IL.

Sheets, W.A. 1973. Chemical pruning of caneberries with dinoseb at Aurora. Proc. West. WA Hort. Assoc. 63:150-152.

USDA-NASS. 2016. Processed red raspberry in the US and Washington, 2015 summary. 28 Sept. 2016. <https://www.nass.usda.gov>. 